\title{
Recorreguts geològics i mineralògics per la comarca de l'alt Palància: des de Viver a Teresa, Begís, Torás, al Toro i a Barracas
}

\author{
Josep Maria Mata-Perelló \\ Joaquim Sanz Balagué \\ Jaume Vilaltella Farràs
}

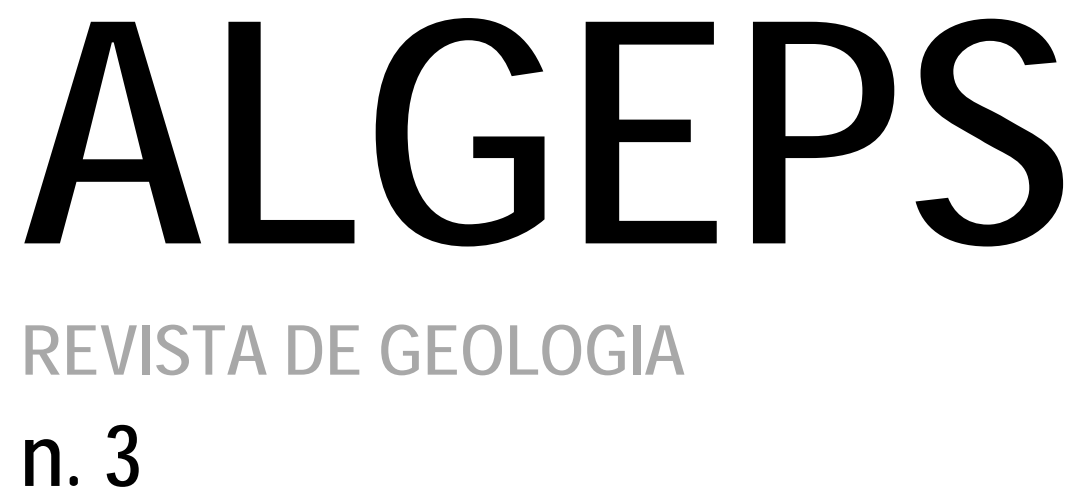

JULIOL 2014 


\title{
RECORREGUTS GEOLÒGICS I MINERALÒGICS PER LA COMARCA DE L'ALT PALÀNCIA: DES DE VIVER A TERESA, BEGÍS, TORÁS, AL TORO I A BARRACAS
}

\author{
Josep Maria Mata-Perelló \\ Museu de geologia Valentí Masachs, Escola Politècnica Superior d'Enginyeria de Manresa \\ (EPSEM), Universitat Politècnica de Catalunya · BarcelonaTech (UPC), 08272 Manresa, Spain
}

\section{Joaquim Sanz Balagué}

Departament d'Enginyeria Minera i Recursos Naturals (EMRN), Escola Politècnica Superior d'Enginyeria de Manresa (EPSEM), Universitat Politècnica de Catalunya - BarcelonaTech (UPC), 08272 Manresa, Spain

Jaume Vilaltella Farràs

Paraules clau: Patrimoni geològic i miner; Sistema ibèric; País Valencià

\section{Resum}

Itinerari realitzat el dia 7 de desembre del 2013. Aquest itinerari geològic i mineralògic, discorrerà íntegrament dintre del Sistema Ibèric, tot i que molt lluny de la denominada Zona d'Enllaç. Malgrat aquesta circumstància, aquesta zona es troba afectada per fractures de direcció catalana, de rumb NE - SW (i NNE - SSW), fonamentalment.

Així, en aquesta ocasió la totalitat del recorregut es situarà en part dintre dels denominats relleus triàsics de Sagunt (definits per Oriol RIBA et altri, 1976). D'aquesta manera, en la major part dels trajectes anirem trobant afloraments dels diferents materials mesozoics. Aquests en un principi són triàsics, passant després a també trobar-se afloraments dels materials del Juràssic i del Cretàcics, segons els indrets per on discorri l'itinerari.

Per d'altra banda, cal dir que aquest itinerari transitarà per una sola comarca: concretament per la del Alt Palància. Així, s'iniciarà per les immediacions de la població de Viver per a cloure prop de la població de Barracas, al límit septentrional de la comarca, molt prop de la comarca aragonesa de Gúdar - Javalambre (de les terres de Teruel)

Per d'altra banda, cal dir que aquesta comarca és una de les que composen la Regió de Segorbe / Sogorb. 


\section{Objectius fonamentals}

Els objectius fonamentals que es pretenen aconseguir en la realització d'aquest itinerari, es poden concretar en els següents aspectes generals, d'acord amb el sentit de la marxa:

1. Estudi i observació dels materials mesozoics, que constitueixen el Sistema Ibèric, per on discorrerà la totalitat del recorregut de l'itinerari, entre les poblacions de Viver i Barracas. Aquests materials pertanyeran en bona part al Mesozoic (repartint-se entre el Juràssic, el Cretàcic i el Triàsic).

2. Observació de les estructures del Sistema Ibèric, dintre dels trams dels recorregut. Aquestes estructures es troben constituïdes en la seva major part per fractures de diverses direccions, fonamentalment de les estructures "ibèriques" i de les estructures "catalanes". En el primer cas de direcció aproximada: WNW - ESE i en el segon NE - SW, gairebé perpendiculars.

3. Observació del congost corresponent al "naixement del riu Palància", a la vessant septentrional de Peña Escabia (al terme de Begís).

4. Observació dels diferents indrets relacionats amb el nostre Patrimoni Geològic que anem trobant al llarg del recorregut de l'itinerari, i en especial dels que puguin ésser catalogats com a LIG (Llocs d'interès Geològic). Algun d'aquests indrets pot ser l'anomenat Naixement del riu Palància, just al contacte entre els materials carbonatats mesozoics i els gres-argilencs del Buntsandsteim. Tanmateix, farem esment del poljé de Toro i el Poljé de Barracas que veurem a les darreres aturades.

5. Observació dels diferents indrets relacionats amb el nostre Patrimoni Miner que anem trobant al llarg del recorregut de l'itinerari, i en especial dels que puguin ésser catalogats a LIPM (Llocs d'Interès del Patrimoni Miner). Dintre d'aquest apartat, farem esment de la Teuleria de Toro.

\section{Antecedents}

No tenim coneixement de cap antecedent bibliogràfic relatiu al recorregut del present itinerari, ni nostre ni de cap altre autor. Tot i així hi ha dos antecedents nostres: Mata -.Perelló I Vilaltella Farràs (2005 i 2011), en un recorregut força semblant al que ara presentem.

En relació a les característiques geològiques farem esment de dos treballs generals, relatius al conjunt dels Països Catalans: GuimerÀ et altri (1992), i Riba et altri (1976). Igualment, cal fer esment dels diferents fulls del Mapa Geológico de España corresponents a la zona per la qual discorrerà el recorregut de l'itinerari.

En relació al Patrimoni Miner, farem esment d'un treball molt recent nostre: Mata - Perelló et altri (2012).

Tots aquests treballs esmentats, i d'altres, figuraran per ordre alfabètic a l'apartat dedicat a la bibliografia. 


\section{Recorregut de l'itinerari}

El recorregut de l'itinerari s'iniciarà a la població de Viver, des d'on es sortirà cap al ponent, per tal d'anar cap a la propera població de Teresa, per las carreteres CV - 2352, CV - 236 y finalment por la CV - 235 En aquest recorregut es faran les primeres aturades: una d'elles en sortir de la població de Viver, i les altres dos poc abans d'arribar a Teresa.

Després el recorregut es dirigirà cap a Begís, seguint inicialment la carretera CV - 235; però abans d'arribar a la Venta de Begís, es faran dues aturades més, totes dues a la vora de la carretera i del riu Palància. Després, el recorregut es dirigirà cap a la població de Begís, per tal d'anar cap al naixement del riu Palància.

Seguidament, es retornarà cap a Begís, des d'on s'anirà cap a Toràs, seguint ara la carretera local CV - 239 per on es faran les darreres aturades del recorregut. Després, el recorregut es dirigirà cap a Toro, per on farem una aurada abans d'arribar-hi, i cap a Barracas (anant ara per la carretera local CV - 240), per on s'acabaria el recorregut de l'itinerari.

Així, en arribar a la cruïlla amb la carretera nacional N-234, finalitzarà el recorregut, tocant a la comarca aragonesa de Gúdar - Javalambre, situada al Sud de Teruel.

\section{Advertiments previs}

Com en altres recorreguts de recerca geològica i mineralògica ..., si es disposa del temps suficient, poden efectuar-se passant per totes les parades i filloles. En cas contrari, recomanem prescindir de les anomenades parades - condicionals.

També cal tenir en conte que una part del recorregut final de l'itinerari, es realitzarà per camins de terra, per la qual cosa caldrà prendre les degudes precaucions. Així, d'aquesta manera es circularà pels diferents camins d'accés a algun dels punts d'observació. Aquest és el cas dels camins d'aproximació cap el congost del "naixement del Palància".

Cal tenir, com sempre, una cura molt especial de respecte a la natura, al llarg de tot el recorregut de l'itinerari, i també fora d'ell.

\section{Descripció de l’itinerari}

Com en altres itineraris, a continuació veurem una sèrie de "parades o estacions". En cada una d'elles es farà un breu comentari, ja sigui de caràcter geològic, geomorfològic o mineralògic, segons s'escaigui.

Per d'altra banda, darrera del nom de l'indret (o de la parada), situarem entre parèntesi el número del Mapa Topogràfic, a escala 1:50.000, on es troba l'indret de l'aturada. En aquesta ocasió, utilitzarem solament dos fulls de l'esmentat mapa topogràfic; concretament, el 614 (dit de Manzanera) i el 639 (Jerica); tot i que la major part de les aturades es realitzaran en el darrer dels dos fulls esmentats. Al respecte, cal dir que aquests fulls han estat publicats pel Instituto Geográfico y Catastral de España.

Així doncs, la relació general de les aturades que constitueixen aquest itinerari, d'acord amb el sentit de la marxa, és el següent: 


\subsection{PARADA 1 - CONDICIONAL. BARRANCO DE LOS VALLEJOS, (terme municipal de Viver, comarca de I’Alt Palància). (Full 639).}

Tot i que el recorregut de l'itinerari haurà començat al poble de Viver, caldrà sortir per la carretera que es dirigeix cap a ponent, cap a Teresa, Toràs i Begís; això és, la carretera CV 2352. Al poc de sortir, en creuar el Barranco de los Vallejos, caldrà fer una primera aturada, a menys de $2 \mathrm{Km}$ de la sortida.

En aquest breu recorregut, hem anat travessant fonamentalment materials detrítics quaternaris, els quals tapen els materials mesozoics del Juràssic i del Cretàcic, els quals formen part de la Serralada Ibèrica, on estem ara situats.

En aquest Iloc hi ha un aflorament dels nivells basals del Cretàcic (en realitat del trànsit del Juràssic Superior al Cretàcic Inferior). Aquests afloraments es troben constituïts per trams de argiles, gresos, calcolutites i calcàries, fonamentalment. Aquests materials formen part de la Fàcies Weald. Aquests materials es troben parcialment recoberts per terrenys detrítics quaternaris.

\subsection{PARADA 2. CARRETERA A TERESA, $\mathrm{Km} \mathrm{4,} \mathrm{(terme} \mathrm{municipal} \mathrm{de} \mathrm{Teresa,}$ comarca de l'Alt Palància). (Full 639).}

Després de realitzar-se la parada anterior, cal seguir per la carretera que se'n va cap a Teresa. Així, haurem circulat per les carreteres CV - 2352, CV - 236 y finalment por la CV - 235. En aquesta darrera, després de deixar el trencall de Torás, en arribar al Km 4, caldrà fer una nova aturada, a uns $3 \mathrm{Km}$ i escaig de l'anterior.

En aquest recorregut, inicialment hem anat trobant afloraments dels materials esmentats a la parada anterior. Més endavant, hem començat a trobar afloraments dels materials juràssics. Aquests es troben constituïts per nivells de gresos, argiles i calcàries.

En aquest Iloc ens trobem en una interessant discordança entre els materials acabats d'esmentar i els del Pliocè - Quaternari que els cobreixen.

\subsection{PARADA 3. CARRETERA A TERESA, Km 4’2, (terme municipal de Teresa, comarca de l'Alt Palància). (Full 639).}

Després de realitzar-se la parada anterior, cal seguir per la carretera que se'n va cap a Teresa (la CV - 235), per tal de fer un curt recorregut de menys de 0’2 Km, des de la parada anterior. Com al cas anterior, farem l'aturada a la vora de la carretera.

En aquest breu recorregut, hem anat trobant els materials esmentats a la parada anterior, els quals pertanyen al Juràssic. Aquests materials es troben constituïts per trams de calcàries, gresos i calcàries.

En aquest indret es fa palesa una fractura que talla als materials anteriors, els quals es troben recoberts pels terrenys detrítics quaternaris i pliocènics. Per d'altra banda, en aquest indret es veu també una estructura d'escurçament entre els materials anteriors. Tot això és el que es veu a la (fotografia 1). 


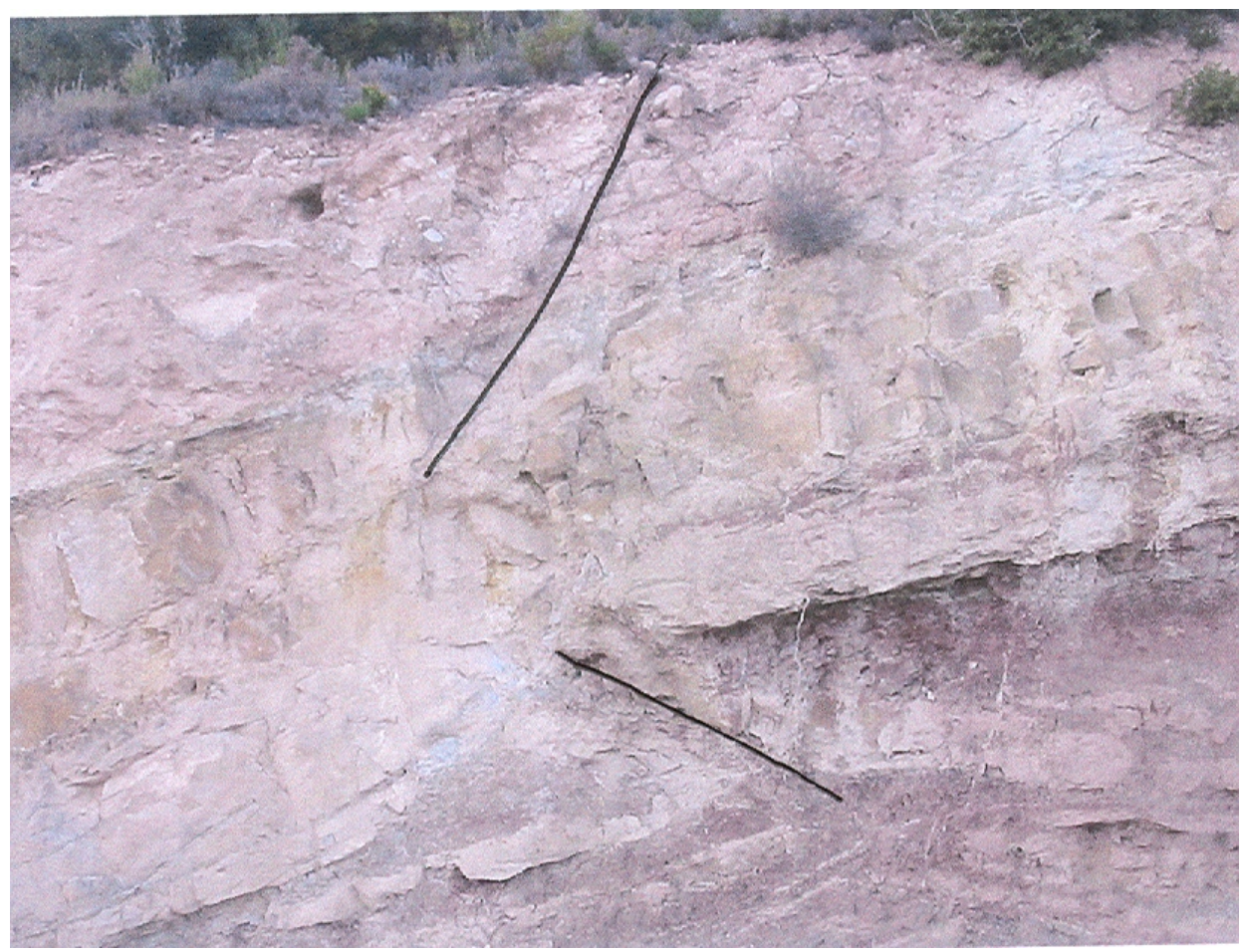

FOTOGRAFIA 1. Un aspecte de les fractures visibles en aquesta aturada

\subsection{PARADA 4 - CONDICIONAL. COLLADO ROYO, (terme municipal de Viver, comarca de l'Alt Palància). (Full 639).}

Després de realitzar-se la parada anterior, cal agafar un camí des de la carretera CV - 235, el qual surt per l'esquerra. Aquest camí se'n va cap al Sud, cap a les immediacions del riu Palància.

En aquest recorregut, haurem trobat els mateixos materials esmentats a la parada anterior, els quals pertanyen al Juràssic.

En aquest indret es fa clarament palès un meandre del riu Palància. Aquest es troba situat entre els afloraments de les calcàries juràssiques.

\subsection{PARADA 5. CARRETERA A BEGIS, Km 9’8, (terme municipal de Teresa, comarca de I'Alt Palància). (Full 639).}

Després de realitzar-se la parada anterior, cal retornar a la carretera CV - 235, per tal de continuar cap a Teresa. En arribar al poble, cal travessar-lo per tal de seguir cap a Begís. En arribar a les immediacions del Km 9'8 cal fer una nova aturada, a quasi $6 \mathrm{Km}$ de l'anterior. 
En aquest recorregut, hem travessat els materials carbonatats juràssics. En arribar a les immediacions del km 9, haurem començat a trobar unes fractures clarament catalanes, de direccions NE-SW.

En aquest lloc es pot fer una observació de les calcàries mesozoiques del Triàsic (concretament del Muschelkalk). Aquestes calcàries es troben intensament fracturades, com a conseqüència de les falles acabades d'esmentar.

\subsection{PARADA 6. CARRETERA A BEGIS, Km 10`2, (terme municipal de Teresa, comarca de l'Alt Palància). (Full 639).}

Després de realitzar-se la parada anterior, cal seguir per la carretera, anant cap a Begís (que continua essent la CV - 235). Just quasi en arribar a la Venta de Begís, caldrà fer una nova aturada, a menys de 0 ' $5 \mathrm{Km}$ de la parada anterior.

En aquest recorregut. Hem anat travessant els materials triàsics. Inicialment hem trobat els carbonatats del Muschelkalk. Tot i això, immediatament hem trobat afloraments del Keuper. Però ben de seguida hem tornat a trobar afloraments dels trams carbonatats. Aquests són els que hi ha a l'indret de l'aturada.

En aquest lloc, aquests materials carbonatats formen el flanc d'un plec. Concretament, es tracta d'un anticlinal, el qual es troba esventrat pel riu Palància. El plec te una clara direcció ibèrica.

Per sobre d'aquests materials afloren els trams argilosos i guixosos del Triàsic Superior, del Keuper.

\subsection{PARADA 7. LA TORRECILLA - RÍOS DE ARRIBA, CARRETERA AL NAIXEMENT DEL PALÀNCIA, (terme municipal de Begís, comarca de I'Alt Palància). (Full 639).}

A continuació de fer l'aturada anterior cal seguir cap a la Venta de Begís, des d'on caldrà seguir cap a Begís. En aquest poble caldrà seguir per la carretera que es dirigeix cap al naixement del Palància. En arribar a les immediacions de la Torrecilla, caldrà fer una nova aturada, a uns $5 \mathrm{Km}$ de l'anterior.

En bona part d'aquest recorregut, hem anat trobant afloraments dels materials triàsics del Keuper. Més endavant, prop de l'indret de l'aturada, hem trobat uns afloraments dels materials carbonatats del Triàsic Mig, concretament del Muschelkalk. Efectivament, com en tot el recorregut, ens trobem plenament situats dintre del Sistema Ibèric, entre afloraments dels materials mesozoics.

Tot i així, en aquest lloc trobarem un aflorament dels materials del Buntsandsteim, per sota dels anteriors. Aquests presenten una direcció gairebé d'E-W, trobant-se inclinats cap al Sud. Així, en aquest lloc es pot fer una observació d'aquests materials del Triàsic Inferior.. 


\subsection{PARADA 8 - CONDICIONAL. MINA DE LOS CLOTICOS, CARRETERA AL NAIXEMENT DEL PALÀNCIA, (terme municipal de Begís, comarca de l'Alt Palància). (Full 639).}

A continuació de fer l'aturada anterior cal seguir cap al naixement del Palància. En arribar i sobrepassar la planta embotelladora de los Cloticos (d'on s'extrau l'anomenada Agua de Begís), ens trobarem un camí que es dirigeix cap a l'altra banda del riu, on hi havia una mineta. Si s'escau, es pot anar. En anar-hi, haurem recorregut quasi $1 \mathrm{Km}$ més.

En aquest recorregut, hem travessat una falla catalana (NE-SW) que posa en contacte els materials del Buntsandsteim amb els del Keuper. Més endavant, en arribar a la mina ens trobarem uns nivells carbonatats del Juràssic. Aquests es troben fallats.

La mina, actualment esfondrada, es trobava en relació a aquesta fractura (de direcció catalana). Els minerals presents eren els de coure, en especial la MALAQUITA. També es trobaven indicis de BARITINA. Un altre mineral present $\mathrm{i}$ abundant en aquest cas, és la CALCITA. A l'actualitat la mina es troba esfondrada i cimentada (gumitada). Tot i així, l'aigua que sorgeix dintre de la mina es canalitzada cap a una bassa, recollint-se i aprofitant-se per a diferents utilitats.

\subsection{PARADA 9. "NAIXEMENT DEL PALÀNCIA", ESTRECHO DEL CASCAJAR (EI Molinar, terme municipal del Toro, comarca de l'Alt Palància). (Full 639).}

A continuació de fer l'aturada anterior cal seguir pel camí que condueix cap al paratge conegut com al naixement del riu Palància, el qual es troba a uns $4 \mathrm{Km}$ més amunt de la Fuente de los Cloticos. En fer aquest recorregut es passa pel poblat del Molinar (des d'on surt un camí que es dirigeix cap el poble de Toro) En arribar a l'indret del naixement del riu, farem la present aturada. Concretament en arribar al paratge del Estrecho del Coscojar.

En aquest recorregut, hem anat trobant afloraments dels materials triàsics. Així, fonamentalment hem trobat els trams de guixos i argiles del Keuper, que són els que es troben cap a la part final del recorregut. Com a la resta del recorregut d'aquest itinerari, estem plenament situats dintre del Sistema Ibèric.

En aquest indret hi ha un interessant congost, de dimensions molt reduïdes, que normalment es coneix amb el nom del naixement del riu, sense ser-ho. En aquest indret es troba al contacte entre els materials triàsics del Keuper, que hem acabat d'esmentar i uns nivells carbonatats del Juràssic. Aquí, el jove riu Palància, circula encaixonat entre aquests nivells del Juràssic. (fotografies 2 i 3 ).

Tot i així, cal considerar que el riu Palància no neix precisament en aquest indret, malgrat el topònim. Aquest riu neix naix una mica més amunt, dintre de la Serra de Toro, molt prop d'on ara som, a un $1 \mathrm{~km}$ aigües amunt. 


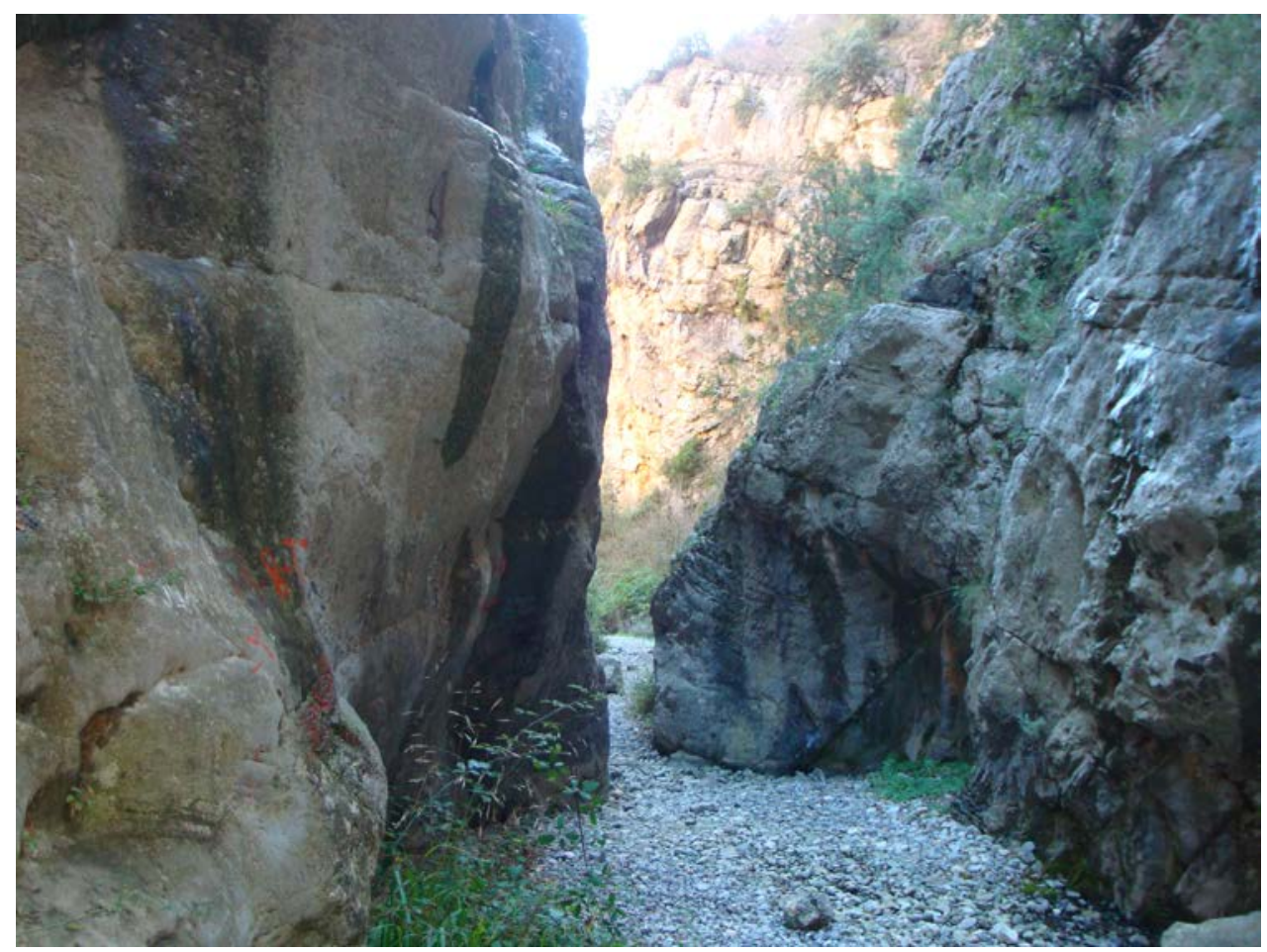

FOTOGRAFIA 2. Un aspecte del naixement del Palància

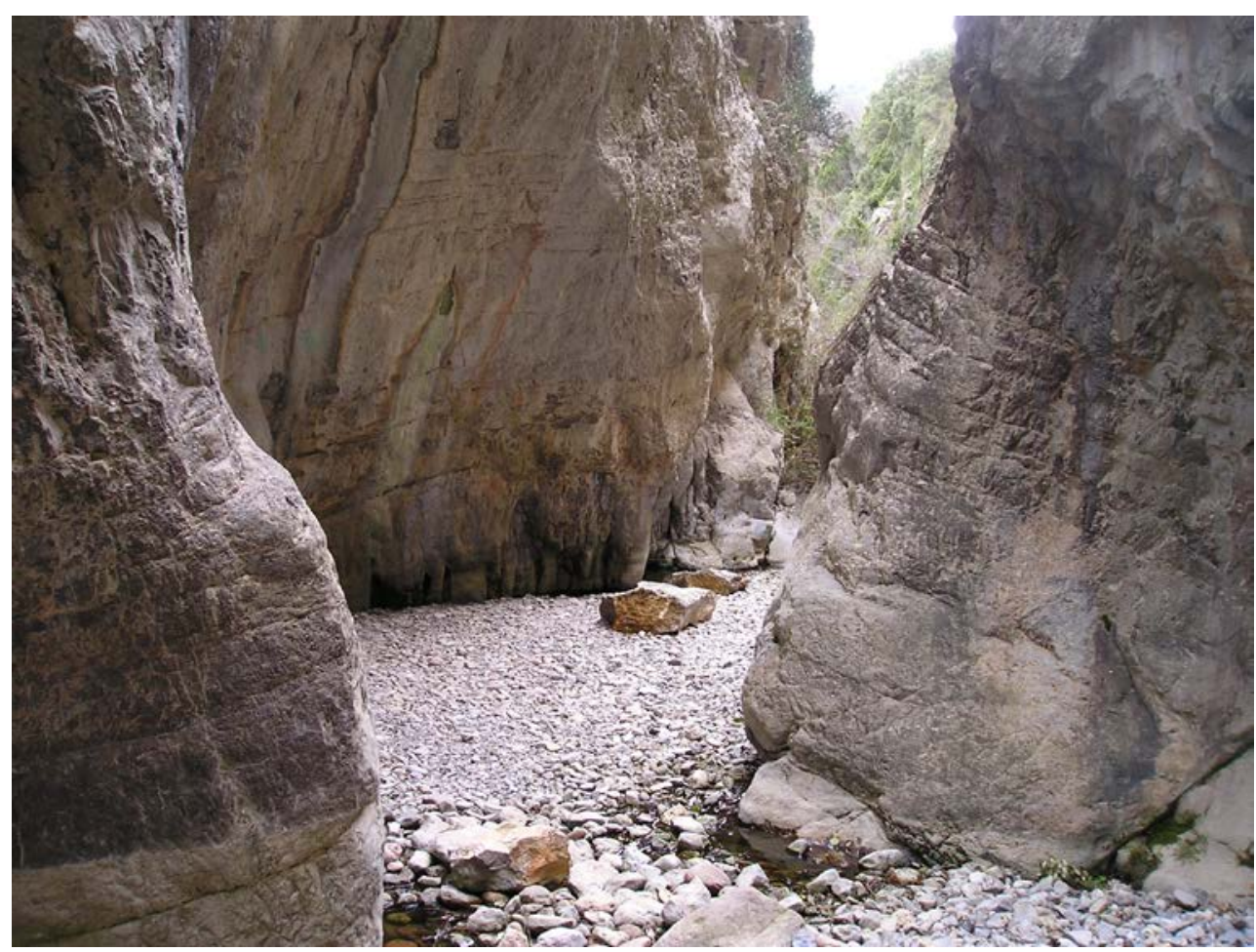

FOTOGRAFIA 3. Un altre aspecte del naixement del Palància 


\subsection{PARADA 10. SORTIDA DE BEGIS CAP A TORÁS, (terme municipal de Begís, comarca de l'Alt Palància). (Full 639).}

A continuació de fer l'aturada anterior cal retornar cap a Begís. En arribar-hi, cal sortir cap al proper poble de Torás, seguint la carretera CV - 239. Tot i així, en sortir del primer poble esmentat, cal fer una nova parada, a uns $8 \mathrm{Km}$ de l'anterior.

En aquest recorregut, hem tornat a tallar els materials mesozoics que hem esmentat en els trajectes cap a les parades anteriors (cap a les aturades 7,8 i 9), en sentit invers a com ho havien fet abans.

Des d'aquest indret, mirant cap a Toràs, es pot veure una interessant falla. Aquesta es troba situada prop de la carretera, i es utilitzada per un torrent, el qual "baixa com un tiro" aprofitant la falla.

\subsection{PARADA 11. CERRO DE LA CRUCETA, (terme municipal de Torás, comarca de l'Alt Palància). (Full 639).}

Després de fer la parada anterior, cal acabar d'arribar al poble de Torás, seguint sempre la carretera CV - 239. En arribar-hi, cal anar cap al Cero de la Cruceta, on farem la present aturada, a uns $5 \mathrm{Km}$ després de fer l'anterior.

En aquest recorregut, hem anat trobant fonamentalment els materials triàsics del Keuper (amb guixos i argiles, fonamentalment). També hem trobat afloraments dels nivells carbonatats juràssics.

En aquest indret hi ha un aflorament de les ofites del Keuper, les quals es troben entre els nivells del Keuper. Al respecte d'aquestes roques, cal dir que en aquest lloc es va intentar la seva explotació. També cal dir que aquestes roques són de característiques subvolcàniques, de composició eminentment bàsica.

\subsection{PARADA 12. TEULERIA DE LA RAMBLA D'ORDUÑA, (terme municipal de Toro, comarca de l’Alt Palància). (Full 639).}

A continuació de fer l'aturada anterior, cal continuar per la carretera CV - 239, anant cap a I'Estació de Begís - Torás. Després, des d'aquí, ens caldrà seguir per la carretereta que es dirigeix cap al poble de Toro. Abans d'arribar-hi. Ens trobarem la Teuleria de la Rambla d'Orduña, a la Hoya del Barbero. Aquí farem una nova aturada, a uns $6 \mathrm{~km}$ al Nord de la parada anterior.

En aquest recorregut, haurem trobat, fonamentalment afloraments dels trams carbonatats del Juràssic. Tanmateix, haurem trobat freqüents fractures que van tallant als materials anteriors. Moltes d'aquestes factures presenten direccions catalanes (majoritàriament de direccions NE$\mathrm{SW}$ ). Sovint aquestes fractures són tallades per altres de direcció ibèrica

(de direcció WNW-ESE), com als darrers trams del recorregut efectuat, per tar d'arribar a la present aturada, tot partint de l'anterior. 
Per d'altra banda, en aquest indret (on s'observa una extensa plana, que correspon a un poljé) hi ha afloraments de materials argilosos. Aquests materials han estat explotats prop d'on ara som, per tal d'utilitzar-se per una interessant teuleria, situada on ara som aturats.

Cal dir que aquesta teuleria es un element interessant del patrimoni miner de la comarca del Alt Palància. (fotografies 4 i 5).

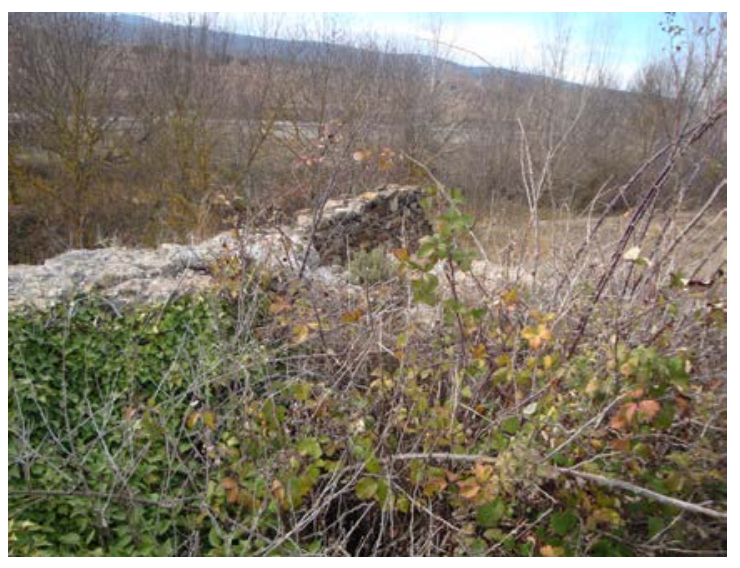

FOTOGRAFIA 4

Un aspecte de la part alta de la teuleria

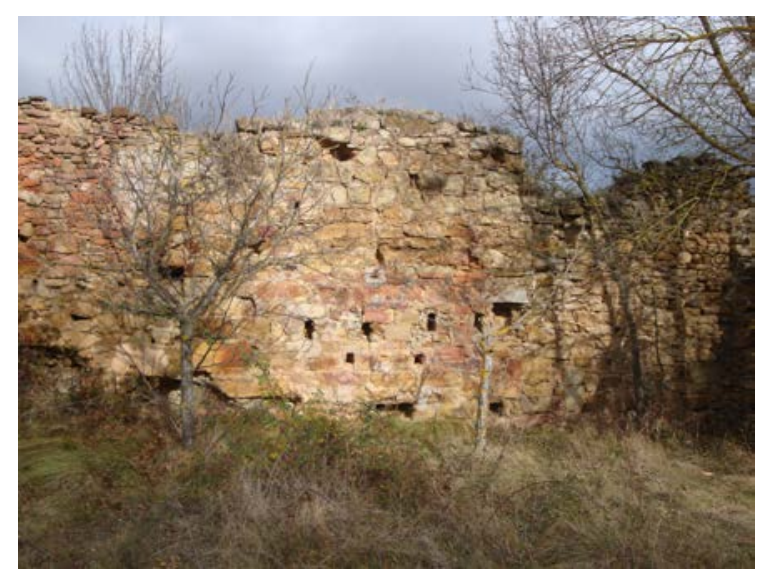

FOTOGRAFIA 5

Part frontal de la Teuleria de Toro

\subsection{PARADA 13. CARRETERA DE BARRACAS A PINA DE MONTALGRAO, (terme municipal de Barracas, comarca de l'Alt Palància). (Full 614).}

A continuació de fer l'aturada anterior, es pot seguir cap a Toro, per tal d'anar després cap a Barracas, seguint ara la carretera local CV - 240. En arribar a aquesta població, cal fer un breu recorregut (de menys de $1 \mathrm{Km}$ per la carretera de Pina de Montalgrao), la CV - 207. En aquest indret farem la darrera aturada, a uns $10 \mathrm{Km}$ de l'aturada anterior.

En aquest recorregut, haurem trobat els materials de les aturades anteriors. Tot i així, en arribar on ara som, s' haurà fet palès un interessant poljé, que es ben visible des d'on ara som, mirant cap al Nord., tal com es veu a la fotografia 6.

En aquest indret finalitza aquest recorregut 


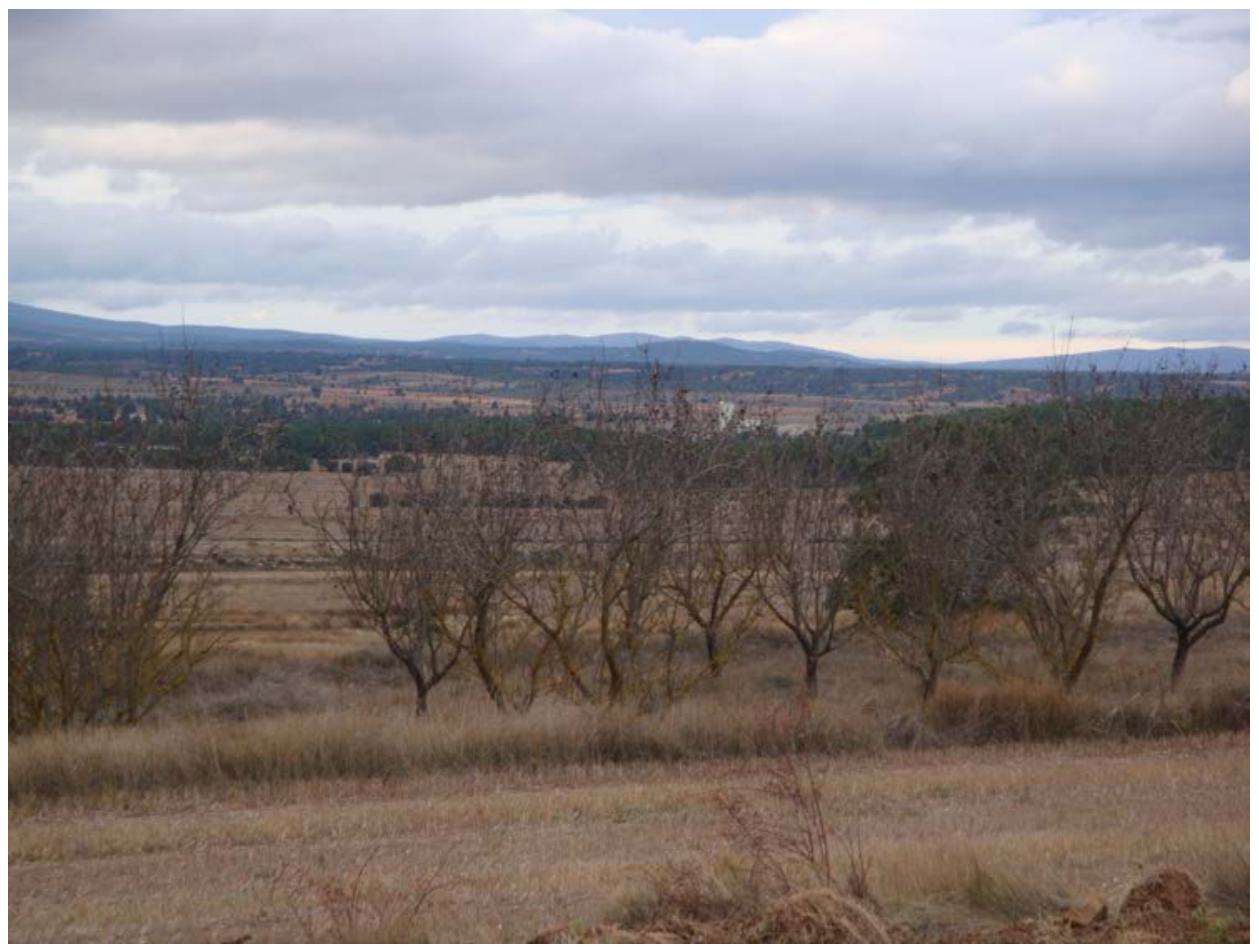

FOTOGRAFIA 6. Poljé de Barracas, des de la carretera a Pina de Montalgrao

\section{Bibliografia}

GUIMERÀ, J. et altri /1992).- Geologia (II), Història Natural dels Països Catalans, Vol.2, 547 pag. Enciclopèdia Catalana, S,A,, Barcelona

IGME (1974).- Mapa Geológico de España, a escala 1:50.000, 2a Sèrie. Hoja i memòria $n^{\circ} 614$ (Manzanera). Inst. Geol. Minero de España. Minist. Indústria. Madrid.

IGME (1974).- Mapa Geológico de España, a escala 1:50.000, 2a Sèrie. Hoja i memòria $n^{\circ} 639$ (Jerica). Inst. Geol. Minero de España. Minist. Indústria. Madrid

LÓPEZ, J. i ARCHE, A. (1986).- Estratigrafia del Pérmico y Triásico, en facies Buntsandsteim y Muschelkalk, en el sector Sudeste de la rama castellana de la Cordillera Ibérica (Provincias de Cuenca y de Valéncia). Estudios Geológicos, nº. 42, pp. 123-143. Madrid

MATA-PERELLÓ, J.M. (1984).- Els Minerals del País Valencià, Col-lecció Informe, nº 6, 546 pàgines. Manresa

MATA-PERELLÓ, J.M. i SANZ BALAGUER, J. (1988).- Guia de determinació de Minerals, adaptada als Països Catalans. Parcir, Edicions Selectes, 207 pàgines. Manresa.

MATA-PERELLÓ, J.M. i VILALTELLA FARRÀS, J. (2005).- Recorreguts geològics i mineralògs per la comarca de l'Alt Palància: des de Viver a Teresa, Begís i a Torás. Inèdit. 8 pag. Manresa 
MATA-PERELLÓ, J.M. i VILALTELLA FARRÀS, J. (2011).- Recorreguts geològics i mineralògics per la comarca de l'Alt Palància: des de Viver a Teresa, Begís, Torás, Toro i a Barracas. Inèdit. 10 pàgines. Manresa

MATA-PERELLÓ, J.M. et altri (2012).- El patrimonio minero de la comarca del Alto Palància (Castellón, Comunidad Valenciana, Sistema Ibérico). Actas del XIII Congreso internacional sobre patrimonio geològico y minero, pp. 743 - 752. Manresa

RIBA, O. et altri (1976).- Geografia Física dels Països Catalans. Edit. Ketres, 254 pàgines. Barcelona. 